\title{
Facade typologies as a tool for selecting refurbishment measures for the Spanish residential building stock.
}

\author{
Elena Cuerda $^{1 *}$, Marlix Pérez ${ }^{1}$, Javier Neila ${ }^{1}$
}

${ }^{1}$ ABIO Research Group, "Arquitectura bioclimática en un entorno sostenible". Department of Construction and Architectural Technology (DCTA). Technical University of Madrid. Av. Juan de Herrera 4, 28040, Madrid, Spain.

*Corresponding author. Tel.: +34 913 363889; fax: +34 913366560 Neila)

E-mail address: e.cuerda@upm.es (Elena Cuerda), fjavier.neila@upm.es (Javier.

\begin{abstract}
Today, the building sector alone accounts for $40 \%$ of the total energy consumption in the European Union (EU). In most EU member states, about $70-90 \%$ of the buildings were constructed at least 20 years ago. Due to this, these buildings have a worse energy efficiency behavior than the new ones that complies with current regulations. As a consequence, acting on the existing building stock is needed, developing special methods on assessment and advice in order to reduce the total energy consumption. This article addresses a procedure allowing the classification and characterization of existing buildings facades. It can help researchers to achieve in-depth knowledge of the facades construction and therefore knowing their thermal behaviour. Once knowing that, the most appropriate upgrading strategies can be established with the purpose of reducing the energy demand. Furthermore, the classified facade typologies have been verified, complying with current and future Spanish regulations and according to the results obtained, a series of upgrading strategies based on the opaque part and those in the translucent part, have been proposed. As a conclusion, this procedure helps us to select the most appropriate improvement measures for each type of facade in order to comply with current and future Spanish regulations. This proposed method has been tested in a specific neighbourhood of Madrid, in a selected period of time, between 1950-1980, but it could be applicable to any other city.
\end{abstract}

Keywords: residential building stock; cataloguing system; facade classification; energy performance; upgrading measures; energy efficient refurbishment.

\section{Introduction}

In recent years in Europe, the importance of improving the energy efficiency in existing buildings has been constantly addressed because the building sector represents $40 \%$ of the European Union's (EU) total energy consumption [1]. In the average Spanish home (Fig 1), the energy consumption due to heating and cooling units, represents $48 \%$ of the total energy use, including: lighting, domestic hot water (DHW), appliances, and climate control systems [2]. Therefore, there is a great potential for energy savings in the existing building stock, that were built according to old regulations, reducing the energy demand in order to achieve more energy-efficient buildings. 


\section{Fig. 1 Energy consumption distribution of households in the residential sector, 2010. Institute for Energy Diversification and Savings (IDAE).}

The Spanish Ministry of Economy and Competitiveness is funding the SHERIFF Research Project, which falls under the INNPACTO program. This project aims to increase the rate of the existing buildings refurbishment from the energy efficiency point of view by designing a facade system that must be an economical, flexible and integrated solution. For this purpose, prior to design the new system, it is necessary to define a procedure that allow the classification and organization of the existing facades and, according to this classification, proposing the most appropriate energy-efficient solution for each type of facade, checking their compliance with regulations. SHERIFF Research Project contains six different work packages and this paper is focused on the first one called "Constructive characterization and energy evaluation of buildings". As well as the work elaborated in this paper, other different tasks are currently under development. The evaluation of the facades energy performance before and after refurbishment will address by monitoring onsite and simulating, in order to discuss the effect of combined interventions and to evaluate the cost/ benefit of these interventions.

This paper pursues the goal of selecting the most appropriate upgrading measure for different type of facades. To this end, it is essential to know how the existing facades were constructed in order to evaluate the energy performance of the existing buildings and subsequently, propose the most appropriate upgrading strategies. For this reason, this paper is divided in the following two parts:

1. Developing a procedure to classify the different types of existing facades.

2. Proposing upgrading strategies, for the classified facades, to comply with current and future regulations.

In the first part of this paper, the classification procedure is framed in a particular time period with the purpose of collecting the maximum available building information. In this article, building information means the architectural project information (drawings and documents) that can help to understand how the building was built. Subsequently, a selection of the neighborhoods of study was done and, within these neighborhoods, the most representative building typologies were chosen. Afterwards, data concerning these representative building typologies was gathered from different sources. A classification of the most representative facades, in terms of their thermal characterization, was concluded based on the data. In other studies, some classifications have been proposed considering general information about the building stock, without a deep insight in the construction of the facade [3, 4]. For example in Denmark, there is a classification that divides the building stock according the specific year of construction [5], but it does not look deeply in the facade construction. Other authors have developed a classification procedure based on in-situ evaluations of the building's energy behavior [4]. This part of the paper is organized as follow: study period selection, procedure of neighbourhoods and building types selection, consulting building information in Public Administrations, classification of facade typologies, and classification of facade typologies, and simplification of cataloguing system. 
In the second part of this paper, the minimum requirements demanded by the Spanish Technical Building Code (CTE) for facades were determined. Then, different improvement actions depending on the climate and location of the existing buildings were proposed for meeting the current regulations. A large demanding requirement was also addressed under the consideration these specifications will be increased, in the coming years, according to the Nearly Zero Energy Buildings demands. This part is organized in the following steps: upgrading measures applied in the facade and, upgrading measures in the translucent part of the facade.

\section{Procedure to classify different types of facades}

In order to facilitate the comprehension of the procedure, a case study has been introduced through the methodology. This case study is framed on a selected period of time, between 1950 and 1980, in a neighborhood in the city of Madrid called Los Ángeles, where SHERIFF project is being developing and thus more information is available.

\subsection{Study period selection}

Building information is usually provided by Public Administrations and to obtain this data can become an arduous process. Moreover, the existing residential building stock is so large and varied in Spain that defining a study period is essential. A chosen period provides the researcher with the building construction types and facilitates his concentration on the changes of thermal behavior due to different layers of the facades [6]. By knowing the thermal behavior, it is possible to provide a better solution on how to upgrade the energy efficiency for each type of facade. Once developed, the methodology for classification can be applied to any study period.

In order to define the study period, most representative historical periods have been selected considering the following aspects: milestones in Spanish technical standards, data collected by the National Statistics Institute, and relevant historical data. The classification of buildings was initially based on the year of construction [6]. The number of buildings was obtained from data taken from the National Statistics Institute.

\section{Fig. 2 Number of buildings per year of construction in Madrid[7]}

\section{Table 1 Total dwellings per type of building from different periods and percentage of each category of the total building stock [8].}

The case study period chosen was between 1950 and 1980 because in that period there was a large increase in housing construction (Fig 2). In Spain, these homes account for more than 8.5 million households, representing more than $35 \%$ of the national total [9]. Additionally, in 1979 the Basic Thermal Conditions in Buildings in Spain were adopted, following the two oil crises in the 1970s, as well as other European countries $[1,10]$. This regulation marked a turning point in the construction of the facades because from that point onwards, thermal insulation began to be used. 


\subsection{Procedure of neighbourhoods and building types selection.}

A selection method was developed to choose the neighborhoods and how many and which buildings were necessary to study in order to have enough information to develop the cataloguing system. To achieve in-depth knowledge of the facades construction, it was necessary to request building information from Public Administrations, as other studies previously have done [11]. In this research, 13 neighborhoods were selected, according to the largest number of homes that were built in the chosen period. Table 2 illustrates the neighborhoods in Madrid, ordered by districts, with more than 10.000 homes built.

Table 2 Neighborhoods with more than 10.000 homes built between 1950 and 1980 [12].

The selection, based on the criterion of the most prevailing facades, was applied for all 13 neighborhoods. Although, in this paper such selection is discussed only considering the case study that has been described at the beginning of this section. These facades were selected throughout the following steps:

1. Downloading the maps of selected districts of Madrid with their respective neighborhood [13].

2. Identification of the limits of the neighborhood selected.

3. Identification and drawing of the boundary of the neighborhood using the Bing Maps tool.

4. Detection of the most representative types of facade construction within the neighborhood.

The Bing Maps tool was used to detect similar building facades. Bird's-eye, a Bing Map tool, provides an elevated view of an object and makes distinguishing different facades possible. (Fig 3)

Fig. 3 Bing maps images of the 5 building typologies selected in Los Ángeles neighborhood.

Five different types of buildings were chosen in Los Ángeles (Fig 3, 4). Several buildings of each type were labeled and listed with the same type of facade in order to be able to request building information to Public Administrations.

Fig. 4 Los Ángeles neighborhood map. Representative building typologies selected.

5. Identification and collection of the complete addresses (street names and numbers) of each building. This information is necessary to request building information, from public administrations, regarding the configuration and parts that make up the facades. 
6. Checking the construction year of the buildings using the Spanish Cadaster [14] to see if they fall in the selected period of study.

\subsection{Consulting building information in public administrations}

In order to know how the selected existing buildings have been constructed, architectural project information was requested. This information is usually provided by the technical departments of municipalities, either from the historical archives of the buildings or from land registers (Cadaster). Each administration uses a different procedure to request information. The architectural project information collected data about location, building and facade construction. About the location, the district and neighbourhood name were requested. It was also important to know the year of construction to check if the building was constructed in the selected period or not. Furthermore, in order to know the size of the building and considering the importance of the accessibility, the number of floors and the lift availability were asked. Finally, information about the constructive description of the roof and facade (opaque and translucent part) was requested. This data included: the number of layers, name of the materials and thicknesses. In the case of the translucent part it was also requested sunshading device type. Despite the fact that building information about 200 architectural projects was requested in all the 13 neighborhoods, we retrieved information only from 59 of them, equivalent to a $30 \%$. In the case study, the building information was found in 3 of the 5 selected typologies (typ_1, typ_2, typ_4). Figures below show the information collected for each typology of building (Fig.5, 6 and 7) in Los Ángeles neighborhood.

Fig. 5 Building information collected about typology 1 of Los Ángeles neighborhood.

Fig. 6 Building information collected about typology 2 of Los Ángeles neighborhood.

Fig. 7 Building information collected about typology 4 of Los Ángeles neighborhood.

\subsection{Classification of facade typologies}

The objective of this task was to obtain an existing facades catalogue that links the building being studied with the appropriate retrofitting measures for each type of facade. This classification was compiled with the building information collected concerning the constructive aspects of the opaque and translucent parts of the facade. Consequently, a code was assigned for each facade type.

Classification was done in four different phases:

Phase I. Every type of facade found in the documentation consulted was collected in this phase. Then, these were classified by separating the facade into two parts as follows: opaque and translucent. The translucent part is divided into three sections: glazing, frame, and solar protection. The first phase ended with a catalogue, that included: 17 different types of the opaque parts of facades, 2 types of glazing, 2 types of 
frames, and 7 types of solar protection. Then, looking for a way to simplify the catalogue, the next phases were developed.

Phase II and III. The phase II of the cataloging system was made to define the main thermal characteristics of the facades. This catalogue was developed taking only intrinsic information of the facade into account, whereas the external climatic factors or building location were not considered because the methodology address a generic procedure that researchers can easily apply._The following characteristics, as defined by the Spanish Technical Building Code (CTE) [15], were considered:

- Solar factor: The ratio of the normal incidence solar radiation that enters the building through the glazing, and that would be introduced if the glazing were replaced by a perfectly transparent hole. In the following tables this characteristic is expressed as g-value.

- Thermal transmittance: The heat flow in steady state divided by the area and the temperature difference of the spaces on either side of the element being considered. In the following tables this characteristic is expressed as U-value.

In the phase III, information about the percentages of each type of facade encountered in the building files consulted was added. Taking thermal characterization of the facades and the percentage of the facade type that was encountered into account, the classification was organized. The result was a classification with 17 entries of different types of opaque part of the facades. It was necessary to develop the next step with the purpose of defining a criterion to simplify and reduce the number of entries.

Phase IV. In this phase, the catalogue was summarized using those types of facades that were encountered at a rate above $5 \%$. These percentages refer to the facade types that were encountered in the total number of buildings consulted in the 2.3 section. The following summary tables (Table 2,3,4 and 5) illustrate the classifications of facades (opaque and translucent parts) that were selected following phases I, II, III and IV.

Table 4 Classification according to the opaque part of the facade.

Table 5 Classification according to the glazing type.

*Data obtained from "Glazing solutions and glazed wall"[16].

\section{Table 6 Classification according to the frame material.}

\section{Table 7 Classification according to solar protection elements.}

According to Table 4, one facade prevailed over all others (F.4). This facade construction was found in $37 \%$ of the cases studied. The percentage of F.1 construction facade was lower, only $16 \%$, and the rest of the configurations were found to be between $5 \%$ and $7 \%$. The building information consulted allowed us to conclude that the houses in this period were predominately constructed with double glass and metal frames.

According to Table 5, the most prevalent glazing type encountered was double glass at $47 \%$. The percentage of double glass was higher than single glass at $37 \%$. The proportion of metal frames with respect to wood frames was $76 \%$ versus $16 \%$ (Table 6 ). None of the cases had thermal bridge breaking. In $47 \%$ of the cases consulted, information regarding solar protection was not found; this represents almost half of 
them. The solar protections identified related mostly to blinds, $32 \%$. Slats and lattices were found in $12 \%$ and $9 \%$ respectively (Table 7 ).

\subsection{Simplification of cataloguing system}

In order to evaluate any existing facade and to decide what the most appropriate action is for each one, a simplification and standardization of the catalogue was made based on the thermal transmittance values of opaque and translucent parts. Thermal transmittance values of opaque parts ranges are defined in the following table. On the other hand, the table 9 shows the thermal transmittance of translucent parts of the facades. $\mathrm{U}_{\mathrm{H}, \mathrm{m}}$ and $\mathrm{U}_{\mathrm{H}, \mathrm{v}}$ correspond to the thermal transmittance values of the frame and the glazing respectively, and $U_{H}$ corresponds to the global thermal transmittance value of the traslucent part of the facades. Table 8 Simplification of the classification of types of opaque part of the facades
depending on thermal transmittance ranges.

Table 9 Simplification of the classification of types of trans/ucent part of the facades depending on thermal transmittance ranges;

\section{Proposed upgrading strategies to comply with current and future regulations}

In Spain, the transposition of the European Directive 2002/91/EC (EPBD) [17] was effected by Royal Decree 314/2006 of 17 March [18] aproving the Technical Building Code. The Spanish Technical Building Code defines climatic zones as a function of the climatic severity which depends on the number of Degree-Days and the Solar radiation [18]. The 52 provincial capitals of Spain are divided in 12 different climatic zones, identified by a letter from A-E (refering to the winter climatic zoning) and a number from 1-4 (refering to the summer climatic zoning). The neighboorhood case study is situated in the provincial capital of Madrid that corresponds with the D3 climatic zone. This corresponds with a clearly continental climate, therefore, is characterized by a radical season contrast with hot and dry summers and cold winters.

The regulatory compliance of the facades was verified using the following: the previous regulation (2006 CTE), the CTE 2013 regulations (has just been published on September 2013), and a 25\% more demanding proposal over the latter. This latter option was taken into account considering that, in the coming years, these requirements will continue to increase in search of Nearly Zero Energy Buildings. According to the Spanish Technical Building Code, the minimun thermal transmittance requirements are defined based on the winter climatic zoning, dividing Spain in 5 climatic zones from A to E. In the opaque part of the facade, comparing Table 8 with Table 10, most of the cataloging facades did not comply with the minimum requirement currently in effect (CTE 2013). Only the types F7 and F8 (thermal transmittance value 1-1.2) complied with the previous regulation (CTE2006) in the A and B climatic zones, corresponding to the warmest areas in Spain. In the translucent part, the most prevalent type encountered was the H4 type. In this case, it only complies with the current regulation in the A 
climatic zone. These results demonstrate that the existing Spanish buildings need urgent renovation to be more energy efficient.

Table 10 Minimum thermal transmittance requirements in translucent and opaque part of the facades, depending on the climatic zone.

\subsection{Upgrading measures applied in the facade}

The upgrading measures studied were applied in the D3 climatic zone. This was the climatic zone that corresponds with the city of Madrid where the case study neighborhood is situated. The different tables show the compliance with the regulations of each type of existing facades adding the upgrading strategies. Each table corresponds with one type of proposed enhancement strategy.

\subsubsection{Upgrading measures in the opaque part of the facade}

One of the most effective energy efficiency improving measures is additional facade insulation [19]. For this reason the upgrading measures, studied in the opaque part of the facade, involved adding external thermal insulation using different thicknesses. Specifically, the upgrading measures were the following:

- Upgrading measure 1 (I1): add external thermal insulation $30 \mathrm{~mm}$ thickness.

- Upgrading measure 2 (I2): add external thermal insulation $40 \mathrm{~mm}$ thickness.

- Upgrading measure 3 (I3): add external thermal insulation $50 \mathrm{~mm}$ thickness.

- Upgrading measure 4 (I4): add external thermal insulation $60 \mathrm{~mm}$ thickness.

- Upgrading measure 5 (I5): add external thermal insulation $80 \mathrm{~mm}$ thickness.

Thermal conductivity data were necessary to calculate the thermal transmittance of the insulation. This information was obtained from the "Building elements catalogue"[20].

Fig. $8 U$ values, from the catalogued existing opaque part of the facades, adding thermal insulation of $30 \mathrm{~mm}$ thickness (I1).

Fig. $9 U$ values, from the catalogued existing opaque part of the facades, adding thermal insulation of 40mm thickness (I2)

Fig. $10 U$ values, from the catalogued existing opaque part of the facades, adding thermal insulation of $50 \mathrm{~mm}$ thickness (I3)

Fig. $11 U$ values, from the catalogued existing opaque part of the facades, adding thermal insulation of $60 \mathrm{~mm}$ thickness (14)

Fig. $12 U$ value of the catalogued existing opaque part of the facades adding thermal insulation of 80mm thickness (I5) 
Figure 8 shows that the facades between F1 and F5, adding thermal insulation of $30 \mathrm{~mm}$ thickness, comply with previous regulation (2006 CTE) and facades F6, F7 and F8 comply with current regulation that was approved in September 2013 (CTE 2013). In conclusion, this measure is not enough to improve the energy efficiency of the opaque part of the majority of the facades. In fact, the most prevalent facade encountered (F5), according to the building files consulted, do not comply even with the current regulation. Figure 9 illustrates, almost all types of the opaque part of the facades, except F1, comply with the current regulation (CTE 2013) when adding thermal insulation of $40 \mathrm{~mm}$ thickness (I2). Moreover, the F8 facade type, complies even with the strictest regulation. The compliance of the upgrading measure 3 with the regulations is represented in figure 10. All facade types satisfy the current requirements, and three of the eight types (F6, F7 and F8), also comply with the more demanding proposal. Figures 11 and 12, indicate that all types of the opaque part of the facades, with adding upgrading measures 4 and 5, satisfy all the requirements studied.

\subsection{Upgrading measures in the translucent part of the facade}

Such as with the opaque part of the facade, the following tables show the compliance of the regulations of the catalogued types of translucent part of the facades taking into account the upgrading measures. The upgrading measures studied were the following:

- Upgrading measure 1 (O1): replace wood and metal frames without thermal bridge breaking with metal frames with thermal bridge breaking.

- Upgrading measure $2(\mathrm{O} 2)$ : replace glazing with a low emissivity glass.

- Upgrading measure 3 (O3): both measures 1 and 2 together.

- Upgrading measure $4(\mathrm{O} 4)$ : add a new window (double window).

Fig. 13. $U$ value of the catalogued existing translucent part of the facades implementing the improvement measure 1 (O1)

Fig. 14. $U$ value of the catalogued existing translucent part of the facades implementing the improvement measure 2 (O2)

Fig. 15. $U$ value of the catalogued existing translucent part of the facades implementing the improvement measure 3 (O3)

Fig. 16. $U$ value of the catalogued existing translucent part of the facades implementing the improvement measure 4 (O4)

Figure 13 illustrates the compliance of the types of translucent part of the facades, with implementing the improvement measure 1, with regulations. The improvement measure O1 had no significant impact on the four different types of studied openings (Table 8). In fact, in the $\mathrm{H} 1$ and $\mathrm{H} 2$ types, their thermal behavior became worse when a wood frame is replaced with a metal frame (even though the metal one had thermal bridge breaking). Only $\mathrm{H} 2$ and $\mathrm{H} 4$ comply with the previous regulation and none of them 
comply with the current and future regulations. As it can be seen in figure14, in the openings $\mathrm{H} 1$ and $\mathrm{H} 3$ (simple glazing) using a low emissivity glass (improvement $\mathrm{O} 2$ ) was a substancial improvement compared to those with double glazing (H2 and H4). Only in the cases $\mathrm{H} 1$ and $\mathrm{H} 2$, with the application of the upgrading measure $\mathrm{O} 2$, the compliance of the current regulation is assured. The implementation of the upgrading measure 3 reduces the $U$ value of the catalogued translucent part of the facades, but none of them comply with current and future regulations (Fig. 15). They only comply with the previous one. In figure 16 is shown that only the types $\mathrm{H} 2$ and $\mathrm{H} 4$ comply with the minimum requirements of current regulation. This improvement O4, which corresponds to the incorporation of a new window, had the greatest influence and complied with all of the studied Spanish requirements.

\section{Conclusions}

The present work has allowed residential existing building stock to be organized using a facade cataloguing system. This catalogue was elaborated taking a specific study period and a selection of different neighborhoods into account. This allowed the result to be more rigorous and detailed so the researchers can now gain a deeper knowledge of these types of construction. It was tested in Madrid and demonstrated that this classified procedure can be successfully applied in any other city following the above-mentioned stages. Once the classification of the existing facades was complete, a proposal of upgrading strategies was made in order to check the compliance with the previous, current and future regulations of these facades in the city of Madrid. In regard to the upgrading measures, they are divided in two different groups: opaque and translucent part of the facade. On the one hand, concerning the opaque part of the facades, adding thermal insulation of $30 \mathrm{~mm}$ thickness (I1) was not enough to improve the energy efficiency of the opaque part of the majority of the facades. In fact, the most prevalent facade encountered (F5), according to the building files consulted, did not comply even with the current regulation. The improvements 2 and 3 had a different influence depending on the type of the facade. And then, the improvements 4 and 5 allow complied all the types of facades with the more demanding proposal of $25 \%$ over 2013 CTE. On the other hand, concerning the translucent part of the facades, replacing wood with metal frames (O1) had no positive impact on the thermal behavior, even though metal frames have thermal bridge breaking. In fact, some cases (H1 and H2) showed a negative effect. In the case of the improvement $\mathrm{O} 2$, low emissivity glass had a greater impact on simple glazing windows than on double-glazing windows. The improvement O4, which corresponds to the incorporation of a new window, had the greatest influence and complied with all of the studied Spanish requirements. Checking the regulation compliance demonstrates that the current Spanish building stock is in dire need and contains the potential to be rehabilitated. As a conclusion, the developed procedure helps us to select the most appropriate improvement measures for each type of facade in order to comply with current and future Spanish regulations. Therefore, it could facilitate faster and more successful decision-making concerning the selection of upgrading measures for refurbishment and it may be a great help for the technicians involved in these processes.

Currently, a study is being conducted on one of the facade types - for energy demand reduction - involving each of the listed improvements by energy simulations. In addition, in the neighboohood of "Los Ángeles", monitoring functions are being performed on the same type of buildings, before and after refurbishment, in order to 
determine the energy-saving impact and learn from the refurbishment work done for future interventions.

\section{Acknowledgements}

Tis work is based on the results of SHERIFF Project that was funded by the Spanish Ministry of Economy and Competitiveness under the INNPACTO program. The authors thank ABIO Research Group and the Department of Construction and Architectural Technology of the Technical University of Madrid (UPM) in Spain. We also thank the Municipal Housing and Land Agency of Madrid and the Municipal Archive of the Madrid Township for allowing the use of their facilities and access to their archives.

[1] Directive 2010/31/EU of the European Parliament and of the Council of 19 May 2010 on the energy performance of buildings.

[2] Institute for Energy Diversification and Savings (IDAE). Spanish Energy Saving and Efficiency Plan 2011-2020. pp.195.

[3] De Luxán, M. et al. Metodología de Evaluación para el Programa de Ayudas a las Actuaciones de Rehabilitación para la Mejora de la Sostenibilidad y Eficiencia Energética de las Edificaciones. SB10mad, Sustainable Building Conference.2010. Madrid, España.

[4] Cuerda, E.; Neila, J.; Procedimiento de análisis y evaluación para la rehabilitación térmica de cerramientos de fachada en edificios residenciales. Caso de estudio en el barrio Pinar del Rey, Madrid. CONAMA (Congreso Internacional del Medio Ambiente).2012.

[5] Tommerup, H.;Svedsen, S. Energy savings in Danish residential building stock. Energy \& Buildings, 2006, vol. 38, no. 6, pp. 618-626.

[6] Dascalaki, E. et al. Building typologies as a tool for assessing the energy performance of residential buildings. A case study for the Hellenic building stock. Energy and Buildings, 2011, vol. 43, no.12, pp.3400-3409.

[7] Spanish Statistical Office. Census of Population and Housing, 2011.Spain. Available from: http://www.ine.es/jaxi/tabla.do?path=/t20/e244/edificios/p04/10/\&file=2mun28.px\&type=pcaxis $\& \mathrm{~L}=0($ accessed 10.8.13)

[8] Valencian Institute of Building. Use of Building Typologies for Energy Performance Assessment of National Building Stock, 2011.Spain. Available from:

http://www.episcope.eu/fileadmin/tabula/public/docs/scientific/ES_TABULA_Report_IVE.pdf (accessed 10.8.13)

[9] Cuchí, A.; Sweatman, P. Una visión-país para el sector de la edificación en España. Hoja de ruta para un nuevo sector de la vivienda. Spain Green Building Council, 2011, pp.25.

[10] Theodoridou, I. et al. A typological classification of the Greek residential building stock. Energy \& Buildings, 2011, vol. 43, no. 10, pp. 2779-2787. 
[11] Dall'O, G. et al. A methodology for evaluating the potential energy savings of retrofitting residential building stocks. Sustainable Cities and Society, 2012, vol. 4, pp. 12-21.

[12] Madrid City Council. Census of Housing, 2001. Available from: http://www.madrid.es/portales/munimadrid/es/Inicio/Ayuntamiento/Estadistica/Planeamientourbano-y-vivienda/Censos-de-Vivienda-

2001? vgnextfmt $=$ default\&vgnextoid $=1 \mathrm{~d} 5 \mathrm{c} 025844 \mathrm{f} 7 \mathrm{e} 010 \mathrm{VgnVCM} 2000000 \mathrm{c} 205 \mathrm{a} 0 \mathrm{aRCRD} \& \mathrm{vg}$ nextchannel $=$ fa $59 \mathrm{c} 4 \mathrm{e} 37504 \mathrm{a} 010 \mathrm{VgnVCM} 100000 \mathrm{~d} 90 \mathrm{ca} 8 \mathrm{c} 0 \mathrm{RCRD} \& \mathrm{rmColec}$ ion $=3 \mathrm{dea} 1 \mathrm{acc} 884$ 8e010VgnVCM1000000b205a0aRCRD (accessed 25.6.13)

[13] Districts of Madrid. Available from: http://www.distritosdemadrid.com/mapa.php (accessed 3.9.12)

[14] Spanish Cadaster. Available from: http://www.sedecatastro.gob.es/ (accessed 12.9.12)

[15] Spanish Technical Building Code (CTE)

[16] Institute for Energy Diversification and Savings (IDAE). "Glazing solutions and glazed wall". $2008 . \quad$ Available from: http://idae.electura.es/publicacion/75/soluciones_acristalamiento_cerramiento_acristalado (accessed 3.9.12)

[17] DIRECTIVE 2002/91/EC OF THE EUROPEAN PARLIAMENT AND OF THE COUNCIL of 16 December 2002 on the energy performance of buildings. Official Journal of the European Communities. L 1/65.

[18] REAL DECRETO 314/2006, de 17 de marzo, por el que se aprueba el Código Técnico de la Edificación.

[19] Nemry et al. Options to reduce the environmental impacts of residential buildings in the European Union-Potential and costs. Energy \& Buildings, 2010, vol. 7, no. 6, pp. 976-984.

[20] Building elements catalogue. Spanish Technical Building Code (CTE), 2010. Available from: http://www.codigotecnico.org/web/galerias/archivos/CAT-EC-v06.3_marzo_10.pdf (accessed 7.4.13) 


\section{Tables}

\begin{tabular}{|c|c|c|c|c|c|c|}
\cline { 2 - 7 } \multicolumn{1}{c|}{} & \multicolumn{2}{|c|}{ Single Unit Houses } & \multicolumn{2}{|c|}{ Multi Unit Houses } & \multicolumn{2}{c|}{ Total } \\
\hline Before 1900 & 767.656 & $11 \%$ & 554.412 & $4 \%$ & $\mathbf{5 5 4 . 4 1 2}$ & $\mathbf{4 \%}$ \\
\hline $\mathbf{1 9 0 0 - 1 9 2 0}$ & 354.954 & $5 \%$ & 369.027 & $3 \%$ & $\mathbf{3 6 9 . 0 2 7}$ & $\mathbf{3 \%}$ \\
\hline $\mathbf{1 9 2 1 - 1 9 4 0}$ & 405.196 & $6 \%$ & 498.539 & $4 \%$ & $\mathbf{4 9 8 . 5 3 9}$ & $\mathbf{4 \%}$ \\
\hline $\mathbf{1 9 4 1 - 1 9 5 0}$ & 435.942 & $7 \%$ & 548.948 & $4 \%$ & $\mathbf{5 4 8 . 9 4 8}$ & $\mathbf{4 \%}$ \\
\hline $\mathbf{1 9 5 1 - 1 9 6 0}$ & 679.882 & $10 \%$ & 1.305 .565 & $9 \%$ & $\mathbf{1 . 3 0 5 . 5 6 5}$ & $\mathbf{9 \%}$ \\
\hline $\mathbf{1 9 6 1 - 1 9 7 0}$ & 761.201 & $11 \%$ & 2.910 .774 & $21 \%$ & $\mathbf{2 . 9 1 0 . 7 7 4}$ & $\mathbf{2 1 \%}$ \\
\hline $\mathbf{1 9 7 1 - 1 9 8 0}$ & 1.084 .141 & $16 \%$ & 3.888 .633 & $27 \%$ & $\mathbf{3 . 8 8 8 . 6 3 3}$ & $\mathbf{2 7 \%}$ \\
\hline $\mathbf{1 9 8 1 - 1 9 9 0}$ & 1.096 .051 & $16 \%$ & 1.781 .978 & $13 \%$ & $\mathbf{1 . 7 8 1 . 9 7 8}$ & $\mathbf{1 3 \%}$ \\
\hline $\mathbf{1 9 9 1 - 2 0 0 1}$ & 1.097 .568 & $16 \%$ & 2.282 .988 & $16 \%$ & $\mathbf{2 . 2 8 2 . 9 8 8}$ & $\mathbf{1 6 \%}$ \\
\hline
\end{tabular}

Table 1 Total dwellings by type of building from different periods and percentages of each category of the total stock [8].

\begin{tabular}{|l|l|c|}
\hline \multirow{2}{*}{ DISTRICTS } & NEIGBORHOODS & $\begin{array}{c}\text { NUMBER OF } \\
\text { DWELLINGS }\end{array}$ \\
\hline \multirow{2}{*}{ HORTALEZA } & Pinar del Rey & 17584 \\
\cline { 2 - 3 } & Canillas & 10668 \\
\hline VILLAVERDE & Los Ángeles & 10115 \\
\hline SALAMANCA & Guindalera & 11320 \\
\hline CHAMARTiN & Prosperidad & 10219 \\
\hline FUENCARRAL & El Pilar & 18669 \\
\hline \multirow{3}{*}{ LA LATINA } & Puerta del Ángel & 12362 \\
\cline { 2 - 3 } & Lucero & 10850 \\
\cline { 2 - 3 } & Aluche & 25245 \\
\cline { 2 - 3 } & Las Águilas & 17813 \\
\hline CARABANCHEL & Vista Alegre & 13895 \\
\hline \multirow{2}{*}{ CIUDAD LINEAL } & Ventas & 17177 \\
\cline { 2 - 3 } & Pueblo Nuevo & 17310 \\
\hline
\end{tabular}

Table 2. Neighborhoods with more than 10.000 homes built between 1950 and 1980 [12]. 


\begin{tabular}{|c|c|c|c|c|}
\hline TYPOLOGY & STREET NAME & NUMBER BUILDING & $\begin{array}{c}\text { YEAR OF } \\
\text { CONSTRUCTION }\end{array}$ & $\begin{array}{c}\text { PUBLIC } \\
\text { ADMINISTRATION }\end{array}$ \\
\hline \multirow[t]{2}{*}{ typ_1 } & CALLE CORTE DEL FARAÓN & $25,27,29,31,33,35$ & 1964 & $\begin{array}{l}\text { Historical Archive of } \\
\text { Madrid, Municipal } \\
\text { Housing Company of } \\
\text { Madrid }\end{array}$ \\
\hline & CALLE CANCIÓN DEL OLVIDO & $\begin{array}{c}10,12,14,16,18,20,22,24,26 \\
28,30,32,34,36,38,40,42,44, \\
46,48 \\
\end{array}$ & 1964 & $\begin{array}{c}\text { Historical Archive of } \\
\text { Madrid,Municipal Housing } \\
\text { Company of Madrid }\end{array}$ \\
\hline \multirow{2}{*}{ typ_2 } & CALLE MANOJO DE ROSAS & $\begin{array}{c}1,3,5,7,9,11,13,15,17,19,21 \\
23,25,27,29,31,33,35\end{array}$ & 1950 & $\begin{array}{c}\text { Urban Agency, Municipal } \\
\text { Housing Company of } \\
\text { Madrid }\end{array}$ \\
\hline & CALLE CORTE DEL FARAÓN & $1,3,5,7,9,11,13,15,17$ & 1950 & $\begin{array}{c}\text { Historical Archive of } \\
\text { Madrid,Municipal Housing } \\
\text { Company of Madrid }\end{array}$ \\
\hline typ_3 & CALLE DE PAN Y TOROS & $\begin{array}{l}14,16,18,20,22,24,26,28,30 \\
32,34,36,38,40,42,44,46,48\end{array}$ & 1952 & $\begin{array}{l}\text { Historical Archive of } \\
\text { Madrid,Municipal Housing } \\
\text { Company of Madrid }\end{array}$ \\
\hline \multirow[b]{2}{*}{ typ_4 } & CALLE ALEGRÍA DE LA HUERTA & $1,3,5,7,9,11,13,15,17,19,21$ & 1972 & $\begin{array}{c}\text { Urban Agency, Municipal } \\
\text { Housing Company of } \\
\text { Madrid }\end{array}$ \\
\hline & CALLE DOLOROSA & $2,4,6,8,10,12,14$ & 1972 & $\begin{array}{l}\text { Historical Archive of } \\
\text { Madrid, Urban Agency, } \\
\text { Municipal Housing } \\
\text { Company of Madrid }\end{array}$ \\
\hline typ_5 & CALLE MANOJO DE ROSAS & $79,81,83,85,87,89,91,93$ & 1970 & $\begin{array}{c}\text { Urban Agency, Municipal } \\
\text { Housing Company of } \\
\text { Madrid }\end{array}$ \\
\hline
\end{tabular}

Table 3 Complete addresses of buildings selected in Los Ángeles neighborhood.

\begin{tabular}{|c|c|c|c|}
\hline & & $\begin{array}{l}\% \text { of the total number } \\
\text { of buildings consulted }\end{array}$ & $\begin{array}{l}\mathrm{U} \text {-value } \\
\left(\mathrm{W} / \mathrm{m}^{2} \mathrm{~K}\right)\end{array}$ \\
\hline F.1 & Solid brick one foot thick & \begin{tabular}{|l|l}
$15.8 \%$ &
\end{tabular} & 2.21 \\
\hline F.2 & Hollow brick 1 foot thick plastered & $5.3 \%$ & 1.05 \\
\hline F.3 & Solid brick one foot thick + air chamber $5 \mathrm{~cm}+4 \mathrm{~cm}$ hollow brick & $7.0 \%$ & 1.22 \\
\hline F.4 & Solid brick $1 / 2$ foot thick + air chamber $5 \mathrm{~cm}+4 \mathrm{~cm}$ hollow brick & $36.8 \%$ & 1,49 \\
\hline F.5 & $\begin{array}{l}\text { Solid brick } 1 / 2 \text { footthick }+5 \mathrm{~cm} \text { air chamber }+ \text { hollow brick } 1 / 2 \\
\text { foot thick }\end{array}$ & $7.0 \%$ & 1.30 \\
\hline F.6 & $\begin{array}{l}\text { Solid siliceous-calcareous brick } 1 / 2 \text { foot thick }+ \text { air chamber } \\
5 \mathrm{~cm}+4 \mathrm{~cm} \text { hollow brick }\end{array}$ & $5.3 \%$ & 1.56 \\
\hline & Other 11 different types & $22.8 \%$ & - \\
\hline
\end{tabular}

Table 4. Classification according to the opaque part of the facade

\begin{tabular}{|c|c|c|c|c|}
\hline \multicolumn{2}{|c|}{ Glazing type } & \multirow{2}{*}{$\begin{array}{l}\% \text { of the total number } \\
\text { of buildings consulted }\end{array}$} & \multirow{2}{*}{\begin{tabular}{|l}
$\begin{array}{l}\text { U-value } \\
\left(\mathrm{W} / \mathrm{m}^{2} \mathrm{~K}\right.\end{array}$ \\
5.7
\end{tabular}} & \multirow{2}{*}{\begin{tabular}{|l}
$\mathrm{g}$-value* \\
0.83 \\
\end{tabular}} \\
\hline V.1 & Simple glazing & & & \\
\hline \multirow[t]{2}{*}{ V.2 } & Double glazing (4-6-4) & 47.2 & 3.3 & 0.75 \\
\hline & No information & 15.8 & - & \\
\hline
\end{tabular}

Table 5. Classification according to the glazing type

*Data obtained from "Soluciones de acristalamiento y cerramiento acristalado" (Glazing solutions and glazed wall)[15] 


\begin{tabular}{|l|l|l|l|}
\hline \multicolumn{2}{|l|}{} & $\begin{array}{c}\text { \% of the total number } \\
\text { of buildings consulted }\end{array}$ & $\begin{array}{c}\text { U-value } \\
\left(\mathrm{W} / \mathrm{m}^{2} \mathrm{~K}\right) *\end{array}$ \\
\hline C.1 & Wood frame & 17.5 & 2.0 \\
\hline C.2 & Aluminum frame & 75.5 & 5.7 \\
\hline & No information & 7 & - \\
\hline
\end{tabular}

Table 6. Classification according to the frame material

\begin{tabular}{|l|l|l|}
\hline \multicolumn{2}{|l|}{} & $\begin{array}{l}\text { \% of the total number } \\
\text { of buildings consulted }\end{array}$ \\
\hline PS.1 & Blinds & 31.5 \\
\hline PS.2 & Slats & 12.5 \\
\hline PS.3 & Lattice & 5.5 \\
\hline & No information & 50.5 \\
\hline
\end{tabular}

Table 7. Classification according to solar protection elements

\begin{tabular}{|c|c|}
\hline & $\begin{array}{c}\mathrm{U} \\
\left(\mathrm{W} / \mathrm{m}^{2} \mathrm{~K}\right)\end{array}$ \\
\hline F1 & 3 \\
\hline F2 & $2-2,2$ \\
\hline F3 & $1,8-2$ \\
\hline F4 & $1.6-1,8$ \\
\hline F5 & $1,4-1,6$ \\
\hline F6 & $1,2-1,4$ \\
\hline F7 & $1-1,2$ \\
\hline F8 & 1 \\
\hline
\end{tabular}

Table 8. Simplification of the classification of types of facades depending on thermal transmittance ranges

\begin{tabular}{|c|c|c|c|c|c|}
\hline & FRAMES & $\mathbf{U}_{\mathbf{H}, \mathrm{m}}$ & GLAZING & $\mathbf{U}_{\mathbf{H}, \mathbf{v}}$ & $\mathbf{U}_{\mathbf{H}}$ \\
\hline H1 & Wood frame & $\mathbf{2 , 2}$ & Simple & $\mathbf{5 , 7}$ & $\mathbf{4 , 5}$ \\
\hline H2 & Wood frame & $\mathbf{2 , 2}$ & Double & $\mathbf{3 , 3}$ & $\mathbf{2 , 9}$ \\
\hline H3 & Metal frame & $\mathbf{5 , 7}$ & Simple & $\mathbf{5 , 7}$ & $\mathbf{5 , 7}$ \\
\hline H4 & Metal frame & $\mathbf{5 , 7}$ & Double & $\mathbf{3 , 3}$ & $\mathbf{4 , 0}$ \\
\hline
\end{tabular}

Table 9 Simplification of the classification of types of opaque part of the facades depending on thermal transmittance ranges 


\begin{tabular}{|c|c|c|c|c|c|}
\cline { 2 - 6 } \multicolumn{1}{c|}{} & \multicolumn{5}{c|}{$\begin{array}{c}\text { CTE 2006 requirements } \\
\text { (previous) }\end{array}$} \\
\cline { 2 - 7 } & A & B & C & D & E \\
\hline $\begin{array}{c}\text { Opaque part of } \\
\text { facade }\end{array}$ & 1,22 & 1,07 & 0,95 & 0,86 & 0,74 \\
\hline $\begin{array}{c}\text { Translucent part of } \\
\text { facade }\end{array}$ & 5,7 & 5,7 & 4,4 & 3,5 & 3,1 \\
\hline
\end{tabular}

\begin{tabular}{|c|c|c|c|c|}
\hline \multicolumn{5}{|c|}{$\begin{array}{c}\text { CTE 2013 requirements } \\
\text { (currently) }\end{array}$} \\
\hline A & B & C & D & E \\
\hline & & & & \\
0,94 & 0,82 & 0,73 & 0,66 & 0,57 \\
\hline & & & & \\
4,1 & 3,3 & 2,9 & 2,5 & 2,6 \\
\hline
\end{tabular}

\begin{tabular}{|c|c|c|c|c|}
\multicolumn{5}{|c|}{$25 \%$ improvement on the 2013} \\
\hline A & B & C & D & E \\
\hline & & & & \\
0,7 & 0,62 & 0,55 & 0,5 & 0,43 \\
\hline 3,08 & 2,48 & 2,18 & 1,88 & 1,95 \\
\hline
\end{tabular}

Table 10. Minimum thermal transmittance requirements in openings and the opaque part of the facades, depending on the climatic zone 
Figures

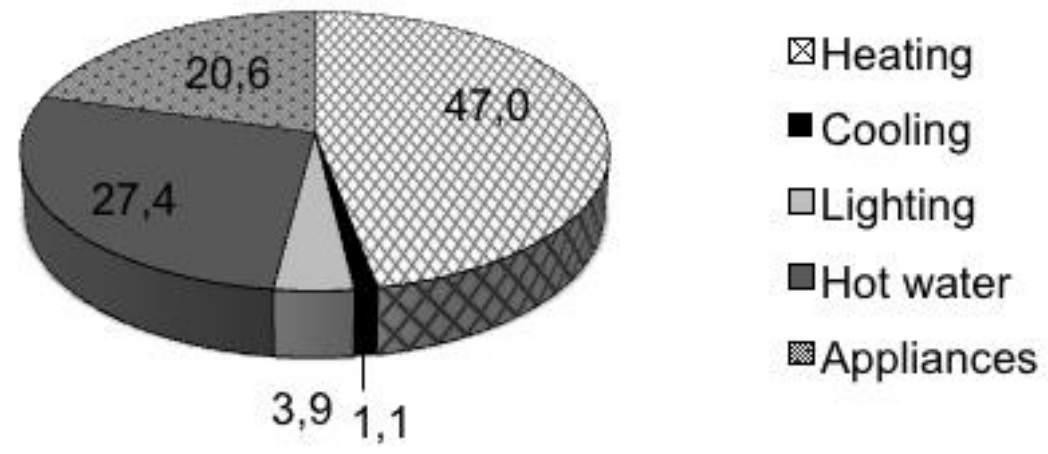

Figure 1. Energy consumption distribution of households in the residential sector, 2010. Institute for Energy Diversification and Savings (IDAE)

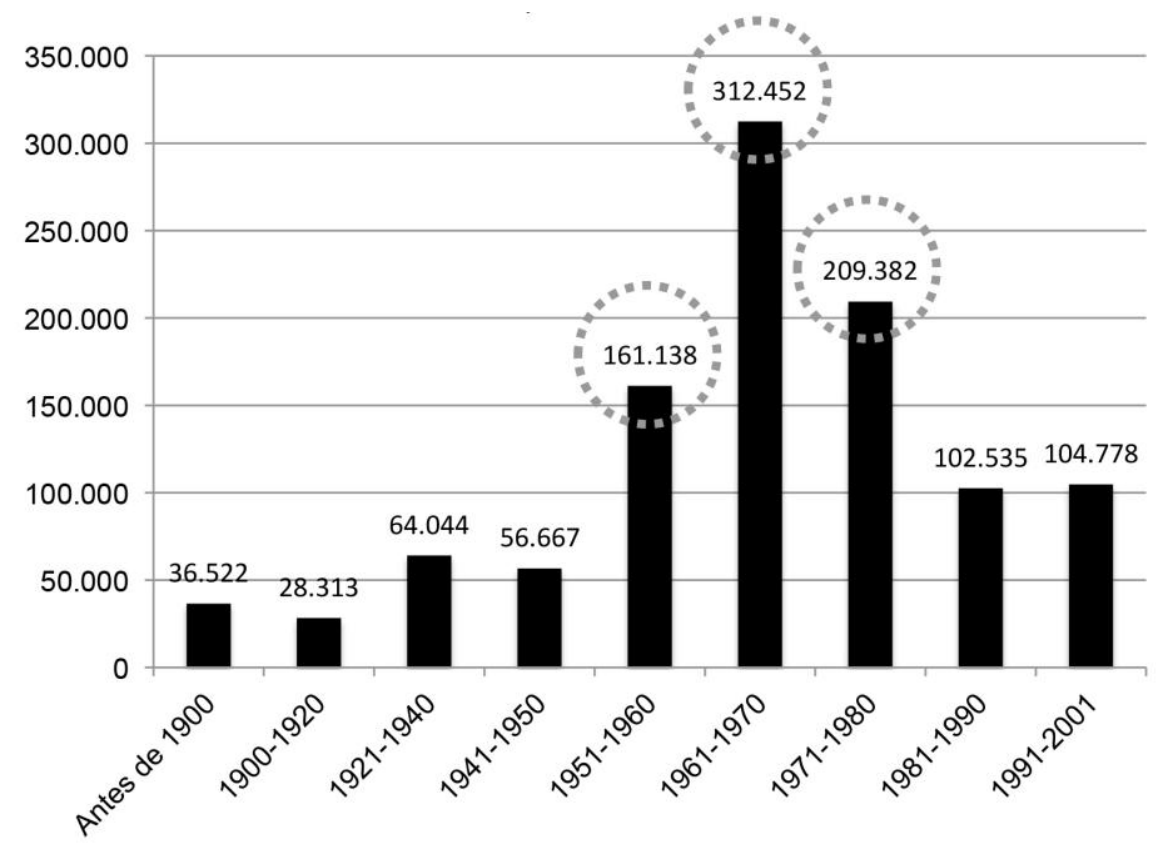

Figure 2. Number of buildings per year of construction in Madrid [7] 


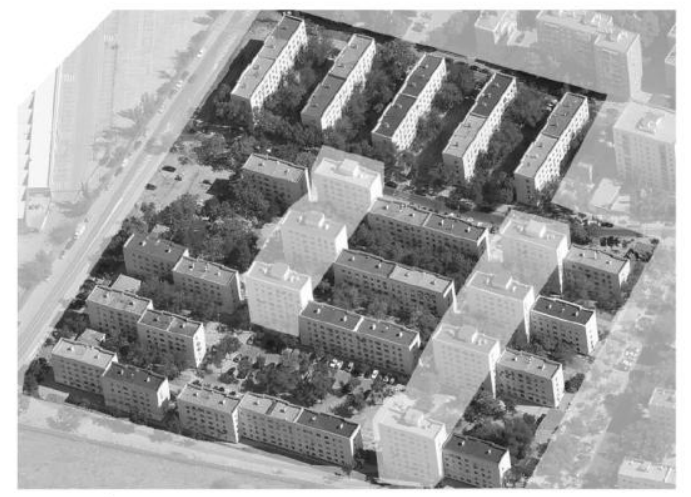

Typology 1

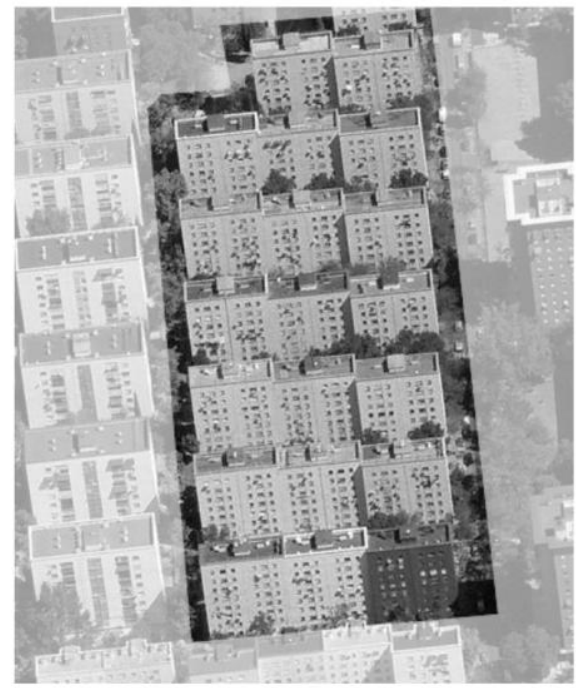

Typology 3

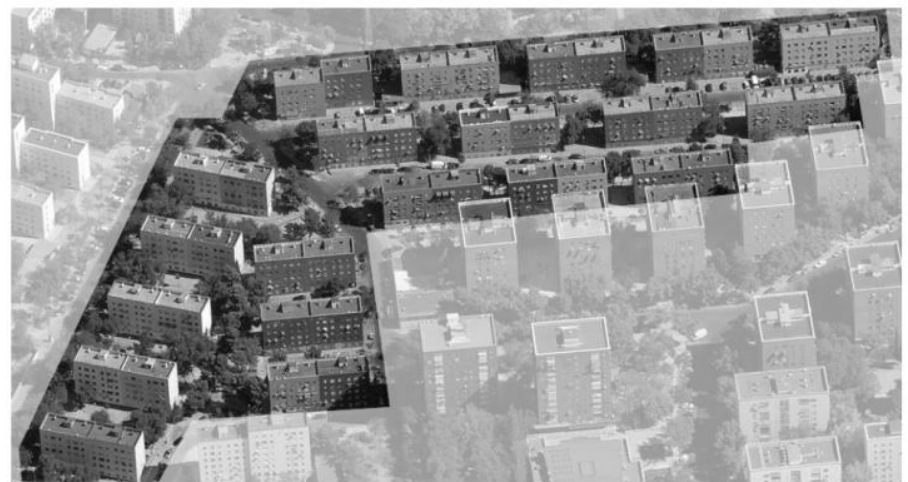

Typology 2

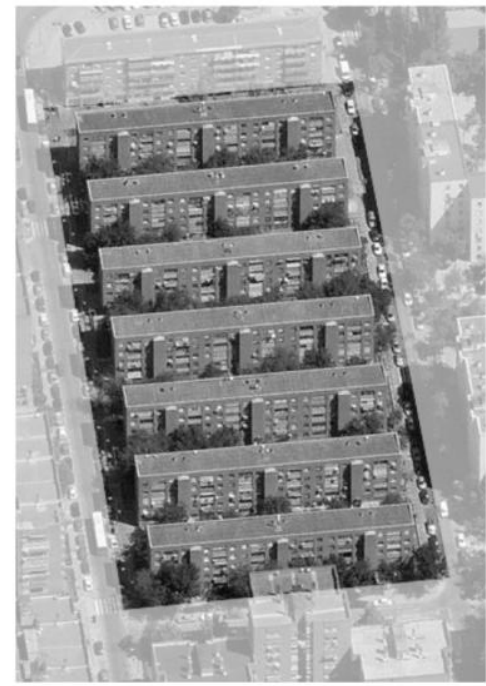

Typology 4

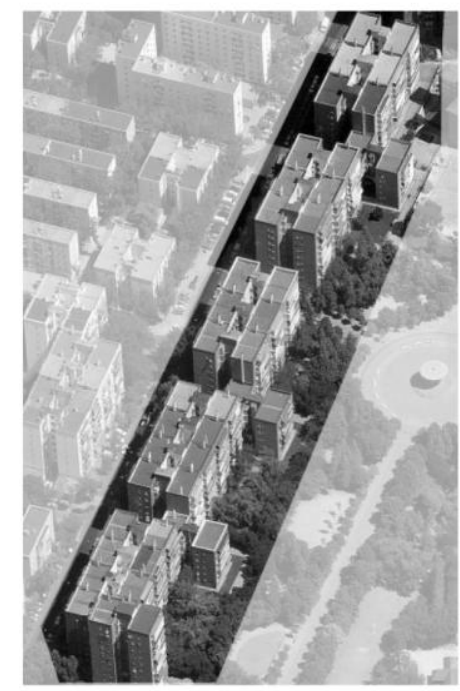

Typology 5

Figure 3. Bing maps images of the 5 building typologies selected in Los Ángeles neighborhood. 


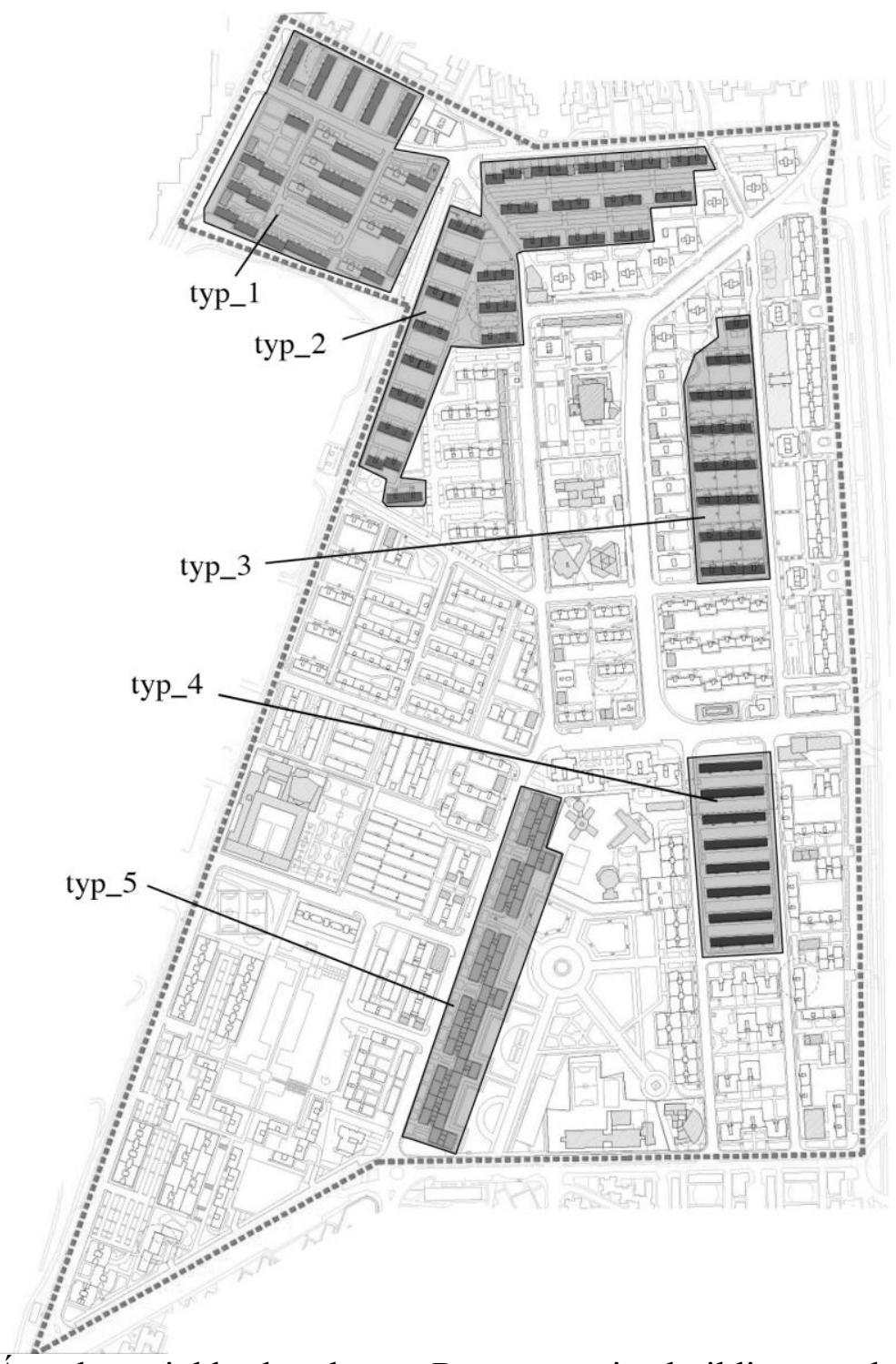

Figure 4. Los Ángeles neighborhood map. Representative building typologies selected. 

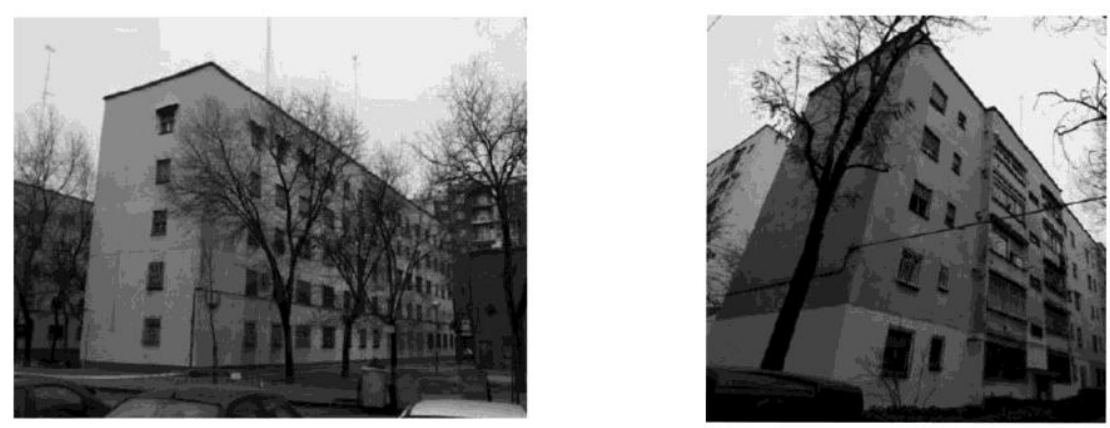

\begin{tabular}{|l|l|c|}
\hline \multirow{4}{*}{ typ_1 } & Year of construction & 1964 \\
\cline { 2 - 3 } & Lift & No \\
\cline { 2 - 3 } & Number of floors & 5 \\
\cline { 2 - 3 } & Opaque part of the facade & $\begin{array}{c}\text { Solid brick 1/2 foot thick + air chamber 5cm }+ \\
\text { 4cm hollow brick + plastered and painted }\end{array}$ \\
\cline { 2 - 3 } & Roof & one-way concrete slabs \\
\cline { 2 - 3 } & Traslucent part of the facade & Aluminium frame \\
\cline { 2 - 3 } & Frame & Single glazing \\
\cline { 2 - 3 } & Glazing & Roller blind \\
\cline { 2 - 3 } & Solar protection & Diorva SA \\
\cline { 2 - 3 } & Promoter & \\
\hline
\end{tabular}

Figure 5. Building information collected about typology 1 of Los Ángeles neighborhood.
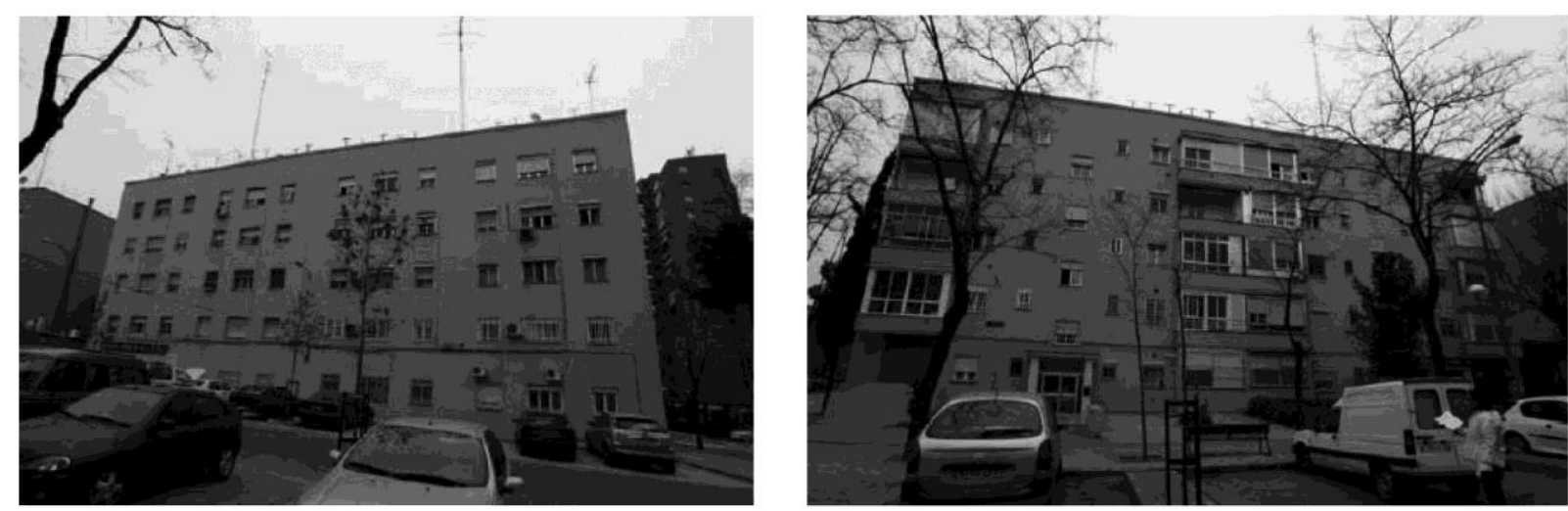

\begin{tabular}{|c|c|c|}
\hline \multirow{10}{*}{ typ_2 } & Year of construction & 1950 \\
\hline & Lift & No \\
\hline & Number of floors & 5 \\
\hline & Opaque part of the facade & $\begin{array}{c}\text { solid concrete wall }(30 \mathrm{~cm} \text { thick })+\text { plastered } \\
\text { and painted }\end{array}$ \\
\hline & Roof & one-way concrete slabs \\
\hline & Traslucent part of the facade & \\
\hline & Frame & Aluminium frame \\
\hline & Glazing & Single glazing \\
\hline & Solar protection & Roller blind \\
\hline & Promoter & Diorva SA \\
\hline
\end{tabular}

Figure 6. Building information collected about typology 2 of Los Ángeles neighborhood. 

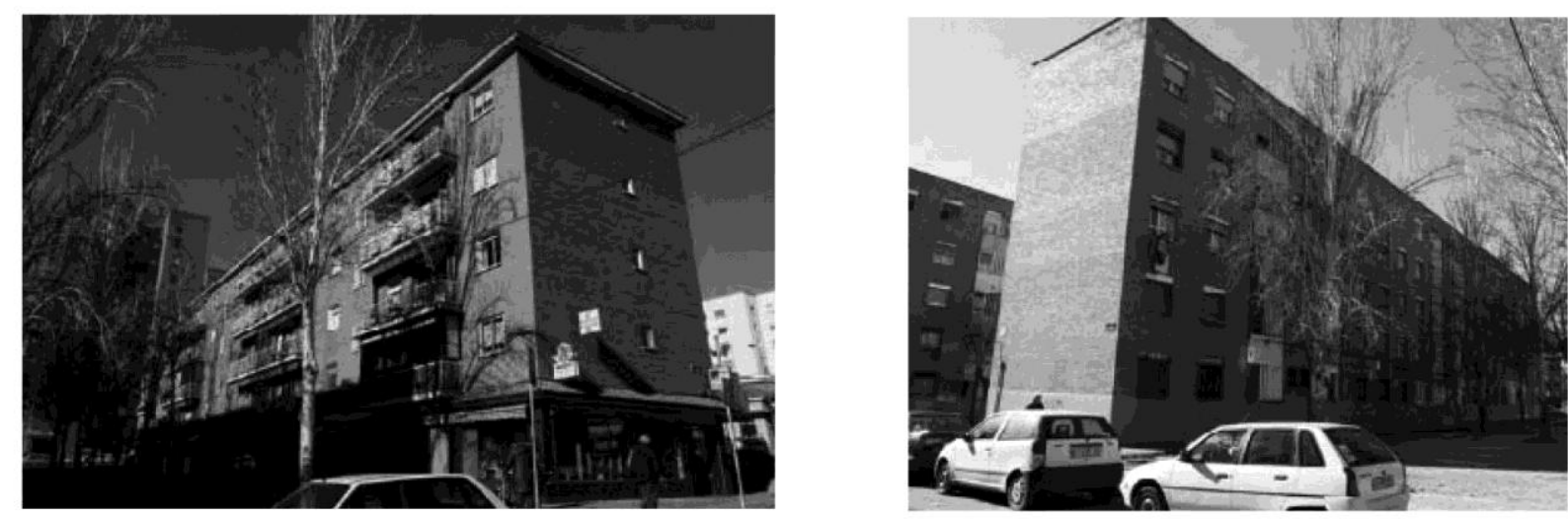

\begin{tabular}{|l|l|c|}
\hline \multirow{4}{*}{ typ_4 } & Year of construction & 1972 \\
\cline { 2 - 3 } & Lift & No \\
\cline { 2 - 3 } & Number of floors & 5 \\
\cline { 2 - 3 } & Opaque part of the facade & Solid brick one foot thick \\
\cline { 2 - 3 } & Roof & one-way concrete slabs \\
\cline { 2 - 3 } & Traslucent part of the facade & Aluminium frame \\
\cline { 2 - 3 } & Frame & Single glazing \\
\cline { 2 - 3 } & Glazing & Roller blind \\
\cline { 2 - 3 } & Solar protection & Virelsa SA \\
\cline { 2 - 3 } & Promoter & \\
\hline
\end{tabular}

Figure 7. Building information collected about typology 4 of Los Ángeles neighborhood.

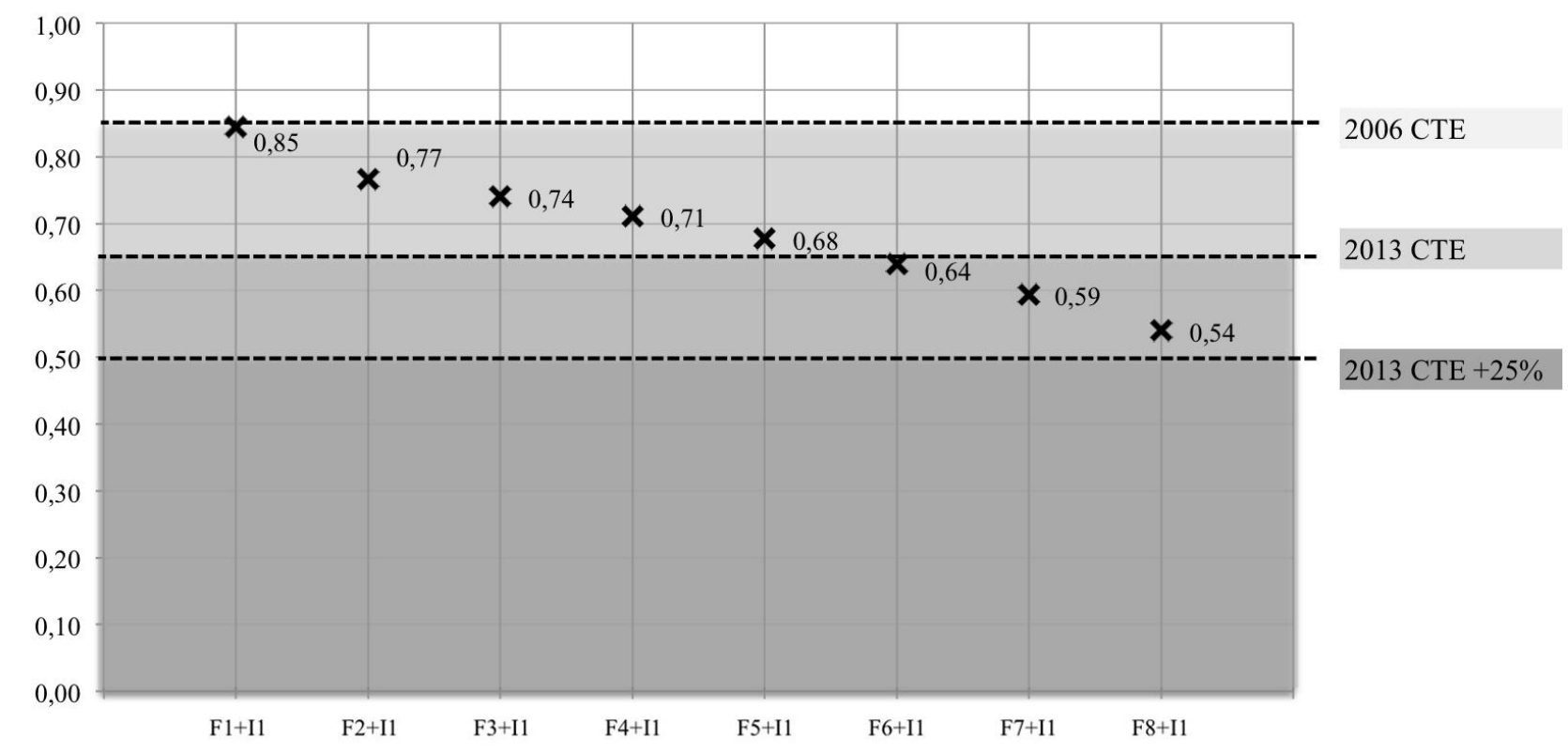

Fig. $8 \mathrm{U}$ values, from the catalogued existing opaque part of the facades, adding thermal insulation of $30 \mathrm{~mm}$ thickness (I1). 


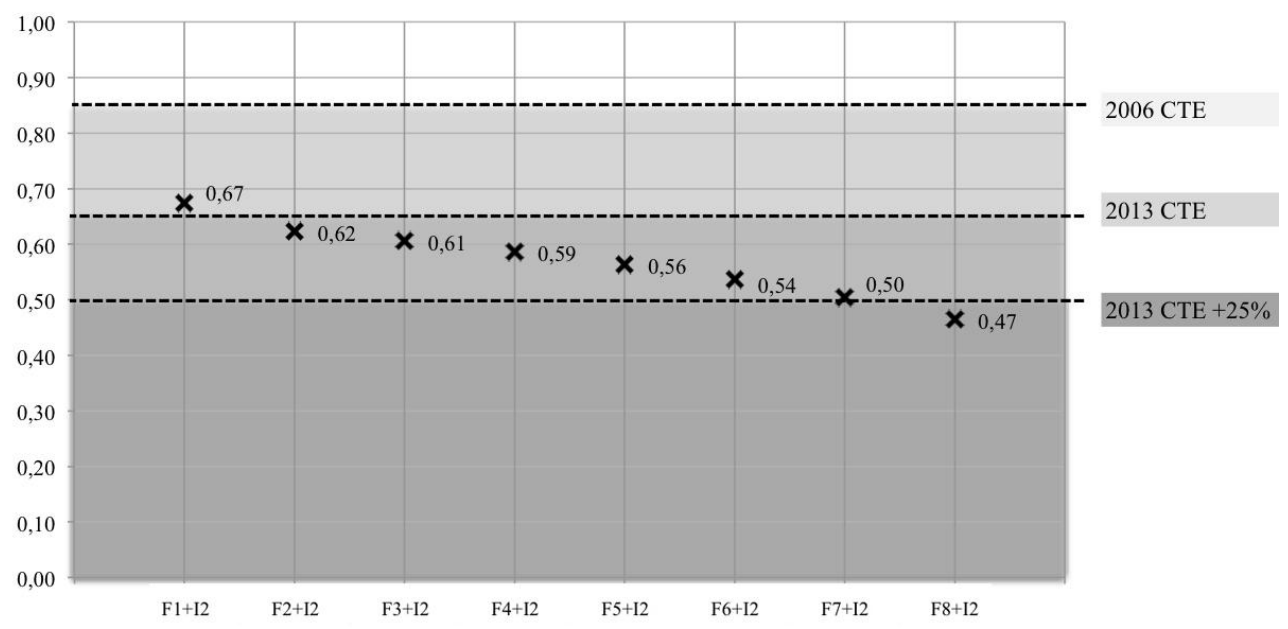

Fig. $9 \mathrm{U}$ values, from the catalogued existing opaque part of the facades, adding thermal insulation of $40 \mathrm{~mm}$ thickness (I2)

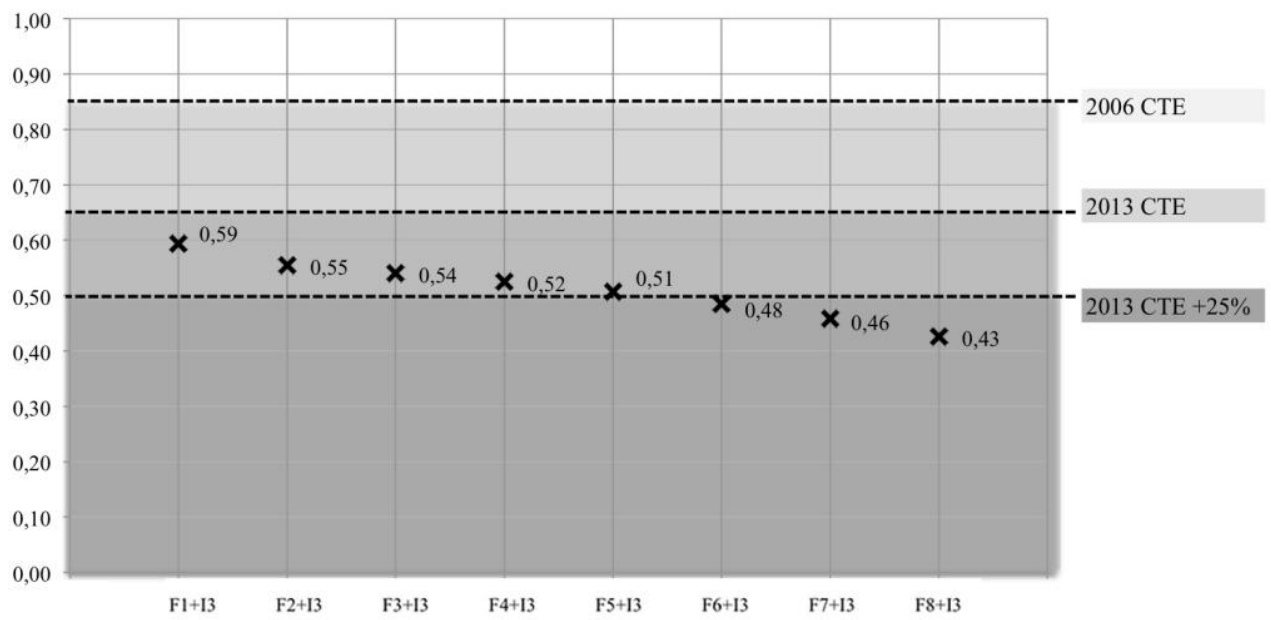

Fig. $10 \mathrm{U}$ values, from the catalogued existing opaque part of the facades, adding thermal insulation of $50 \mathrm{~mm}$ thickness (I3) 


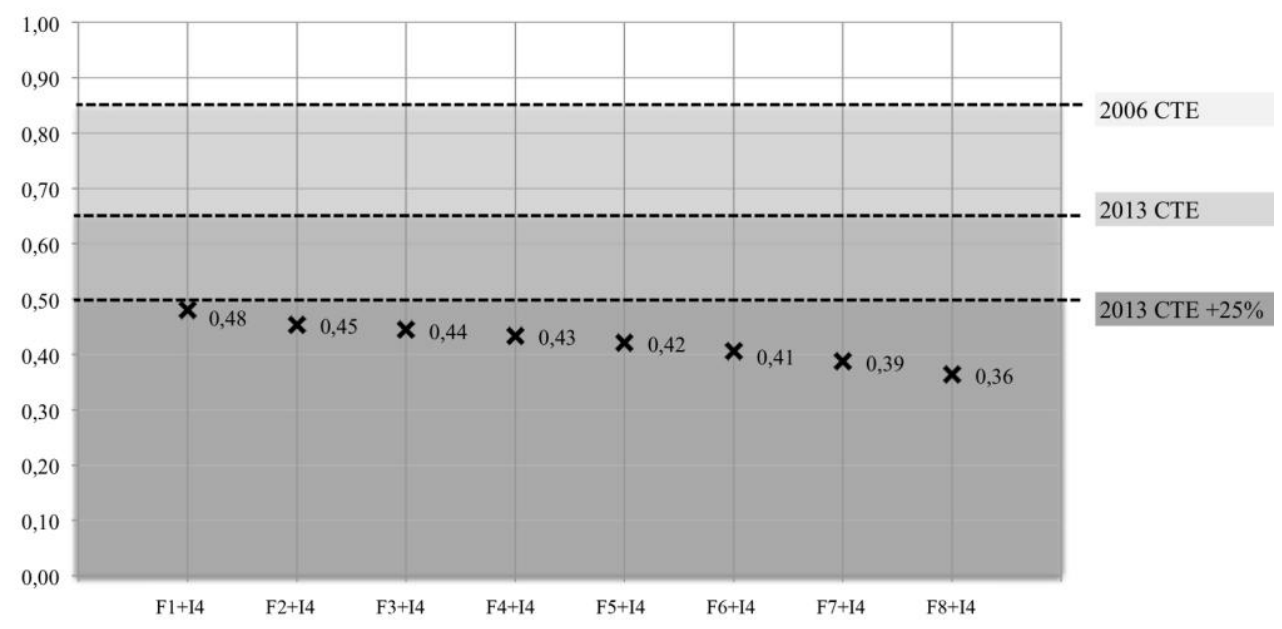

Fig. $11 \mathrm{U}$ values, from the catalogued existing opaque part of the facades, adding thermal insulation of $60 \mathrm{~mm}$ thickness (I4)

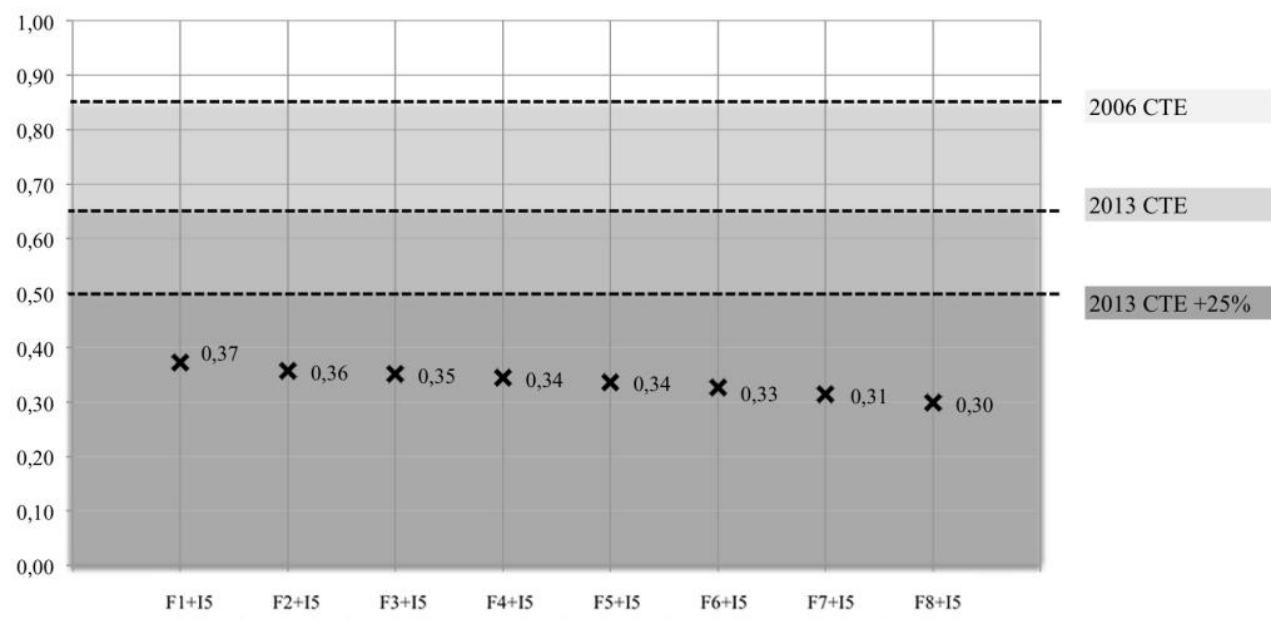

Fig. $12 \mathrm{U}$ value of the catalogued existing opaque part of the facades adding thermal insulation of $80 \mathrm{~mm}$ thickness (I5) 


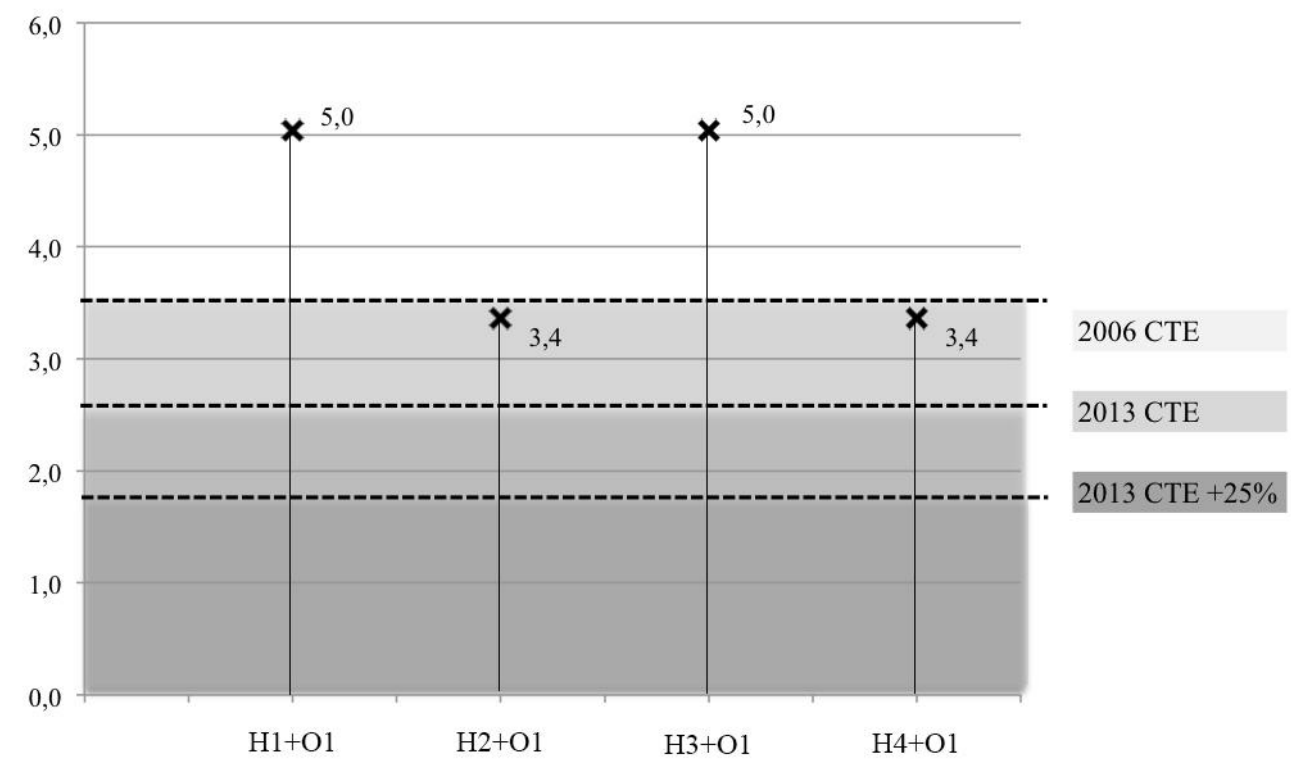

Fig. $13 \mathrm{U}$ value of the catalogued existing translucent part of the facades implementing the improvement measure $1(\mathrm{O} 1)$

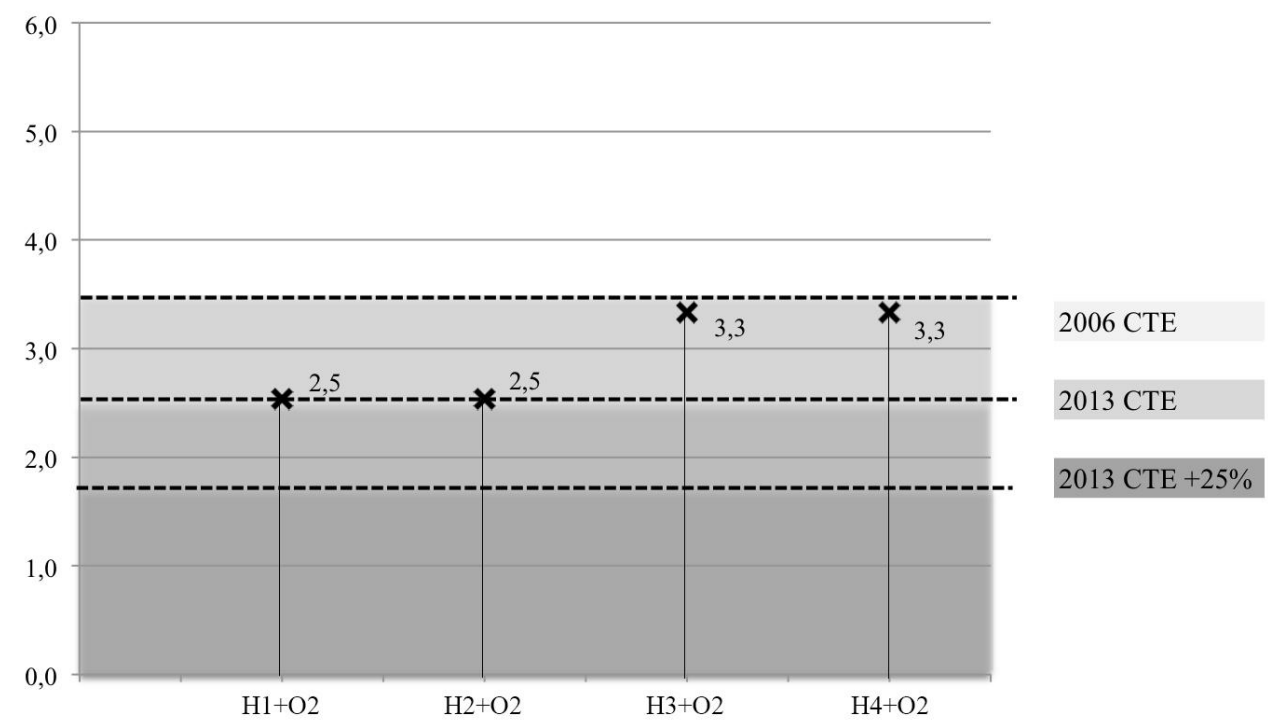

Fig. $14 \mathrm{U}$ value of the catalogued existing translucent part of the facades implementing the improvement measure $2(\mathrm{O} 2)$ 


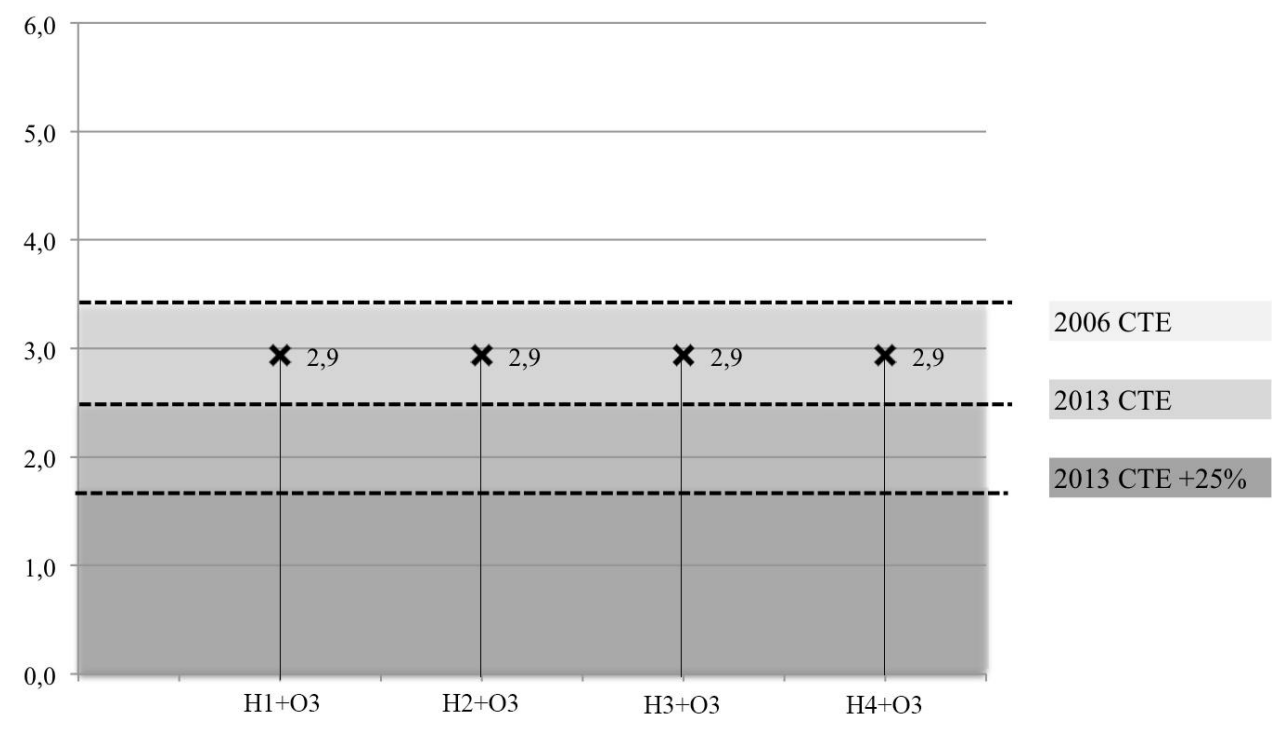

Fig. $15 \mathrm{U}$ value of the catalogued existing translucent part of the facades implementing the improvement measure $3(\mathrm{O} 3)$

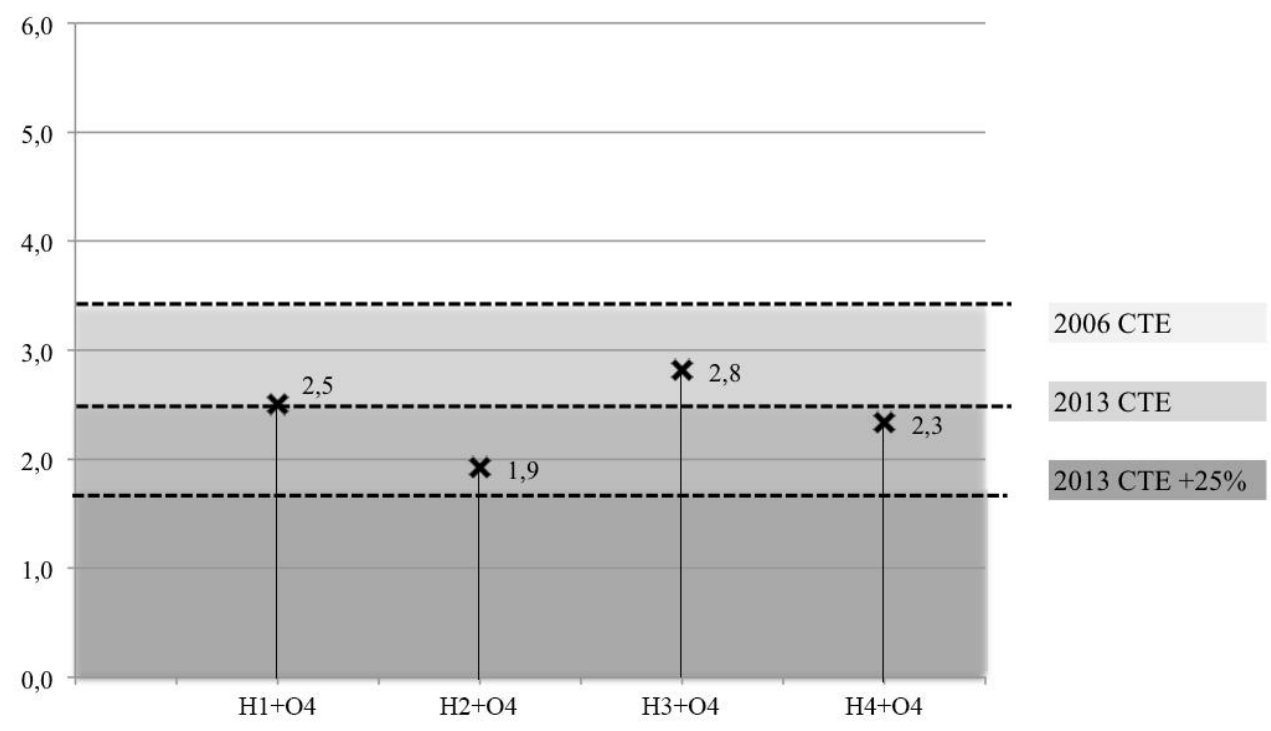

Fig. $16 \mathrm{U}$ value of the catalogued existing translucent part of the facades implementing the improvement measure $4(\mathrm{O} 4)$ 
- Facilitating the decision-making concerning the refurbishment upgrading measures

- A great assistance to the technicians involved in the refurbishment processes

- The facade types classification allow the result to be more rigorous and detailed

- The Spanish building stock contains the potential to be refurbishment

- Checking compliance with regulations is a refurbishment strategy selection support 